\title{
Ability of Desert Rodents to Find Buried Seeds
}

\author{
TERRELL K. JOHNSON AND CLIVE D. JORGENSEN
}

\begin{abstract}
There were significant variations in how many caches of buried Indian rice grass (Oryzopsis hymenoides) seeds were found by Dipodomys microps, Dipodomys ordii, Microdipodops megacephalus, Perognathus formosus, Perognathus longimembris, Perognathus parvus, Peromyscus maniculatus, and Reithrodonotomys megalotis. Success ranged from that of $P$. maniculatus and $R$. megalotis, that failed to find any buried seeds in dry sand, to $P$. formosus, that found $57.5 \%$ of the seeds buried at $0.6 \mathrm{~cm}$, to $M$. megacephalus that found $50 \%$ buried $1.3 \mathrm{~cm}$ deep. Peromyscus maniculatus and $P$. parvus found more buried seeds as the soil moisture was increased.
\end{abstract}

Rodents are not important just as ecological components (Chew and Chew 1970, Brown and Leiberman 1973, Reichman and Oberstein 1977) of western North American desert and grassland range communities; they are also important in some management practices (Howard and Cole 1967, Soholt 1973), particularly reseeding operations. Earlier work demonstrated that desert rodents largely depend on and are partially responsible for dispersal of the seeds from some important range plants (Reynolds 1958). At the same time diversity, density and reproduction of desert rodent populations appear dependent on the abundance and predictability of seed abundance (Brown 1975, Beatley 1969). Since desert rodents are probably food limited and capable of over exploiting their resources (Soholt 1973), they may play an important role in reproduction of range plants. This propensity of rodents to feed on seeds has been a problem with reseeding operations (Howard and Cole 1967)

Before the effects of rodents can be adequately included in range management decisions and before their specific niches in range community maintenance can be modeled, we must understand how they partition their seed resources and how they compete with other herbivores using the range resources. Reichman and Oberstein (1977) reported depth of buried seed as an important criterion used by desert rodents in choosing seeds. As we consider the implications just reviewed, it seems necessary to include the differential abilities of rodents to find buried seeds while formulating management programs to use and maintain western rangelands for livestock and wildlife.

Seeds are reported to be the primary food resource for most desert rodents, particularly heteromyids (Chew and Chew 1970, Brown 1973, Reichman 1975); and since rodent populations fluctuate in response to seed abundance (Brown and Leiberman 1973), competition among desert species may be especially important when seeds are sparse during and following droughts (Reynolds 1958, Mares and Williams 1977) or if grazing reduces seed resources. If desert rodents possess significantly different abilities to find buried seeds, a competitive advantage may accrue to those able to locate seeds more efficiently during periods when seeds are less

\footnotetext{
The authors are graduate student and professor of zoology, Department of Zoology, Brigham Young University, Provo, Utah 84602.

This study was supported by the Department of Zoology, Brigham Young University and the USIBP Desert Biome, Pine Valley studies.

Manuscript received December 17, 1979.
}

abundant. Knowledge of their varied abilities to find buried and clumped seeds could provide a partial explanation for competitive exclusion, coexistence with other species, species distribution, activity patterns, and food resource partitioning.

Although data are few, some discrepancies have been reported within rodent species and significant variation among others with regard to their respective abilities to find buried seeds. Reichman and Oberstein (1977) reported that $28 \%$ of the Arizona pocket mice (Perognathus amplus) detected all seeds buried at $2.5 \mathrm{~cm}, 21 \%$ at $5.0 \mathrm{~cm}$ and none at $7.5 \mathrm{~cm}$; and that $72 \%$ of Merriam's kangaroo rats (Dipodomys merriami) detected all seeds buried at $2.5 \mathrm{~cm}$, $44 \%$ at $5.0 \mathrm{~cm}$ and $11 \%$ at $7.5 \mathrm{~cm}$. Reynolds (1958) reported that Merriam's kangaroo rats found $85 \%$ of the seeds buried at $1.3 \mathrm{~cm}$ and $56 \%$ at $2.5 \mathrm{~cm}$, but Perkins et al. (1976) reported that Merriam's kangaroo rats failed to find seeds buried at depths greater than $1.0 \mathrm{~cm}$ of sand. Lockard and Lockard (1971) found desert kangaroo rats (Dipodomys deserti) could detect $100 \%$ of the seeds buried in $6.0 \mathrm{~cm}$ of soil, $50 \%$ in $10 \mathrm{~cm}$ and $25 \%$ in $20.0 \mathrm{~cm}$, albeit some physical clues were left for the rats. Howard and Cole (1967) reported that $100 \%$ of several seed species buried from 2.5 to $7.6 \mathrm{~cm}$ in commercial peat were detected by deer mice (Peromyscus maniculatus). There appears to be disagreement on the ability of Merriam's kangaroo rats to find buried seeds; and also it appears that Arizona pocket mice and Merriam's kangaroo rats did not find seeds as well as deer mice and desert kangaroo rats, under the conditions of the respective studies.

One plausible explanation for the reported differences among the species' success in finding buried seed could be differences in soil moisture and seed type. Howard and Cole (1967) conducted their experiments with deer mice in commercial peat, which likely contained more moisture than did the sand Perkins et al. (1976) used in testing Merriam's kangaroo rats. Lockard and Lockard (1971) and Reynolds (1958) studied desert kangaroo rats and Merriam's kangaroo rats under field conditions where there were no controls of soil moisture.

The purpose of our study was to determine whether significant variation exists in the ability of desert rodents to find seeds buried in dry sand, and to determine if changing the soil moisture effects their detection abilities.

\section{Materials and Methods}

Ten individuals each of the Great Basin kangaroo rat (Dipodomys microps), Ord's kangaroo rat (Dipodomys ordii), dark kangaroo mouse (Microdipodops megacephalus), long-tailed pocket mouse (Perognathus formosus), little pocket mouse (Perognathus longimembris), Great Basin pocket mouse (Perognathus parvus), western harvest mouse (Reithrodontomys megalotis), and deer mouse (Peromyscus maniculatus) were tested to determine how many caches of Indian rice grass (Oryzopsis hymenoides) seeds would be located when buried within a $1.2 \times 2.4-\mathrm{m}$ experimental laboratory arena at different depths in air-dried sand (Fig. 1). The arena was constructed so the numbers of seeds not located by a rodent after a 24 -hr period could be recovered for counting by releasing the sand through a screen on the bottom of the arena. 
The arena was partially filled with dry sand, then 12 caches of 100 seeds each were placed in or on the sand - four on the surface, four buried at $0.6 \mathrm{~cm}$, and four buried at $1.3 \mathrm{~cm}$. The arena was divided into 98 squares (all buried under the sand) and seed caches placed at random among them (Fig. 1). A test animal, which was previously maintained with food and water ad libitum, was introduced into the arena through an attached nest box and left for 24 $\mathrm{hr}$. Water was not supplied in the arena. After each experiment, the test animal was removed and the sand released through the bottom of the arena, exposing seeds not eaten. Each species was replicated 10 times, totaling 40 seed caches at each depth per species.

To determine the effect of soil moisture, 10 deer mice were tested as described earlier, except 25 seed per cache were used and several humidifiers were operated in the room containing the arena to maintain 70 to $90 \%$ relative humidity during each test. In order to measure the moisture content of the sand, another set of experiments were conducted in which deer mice and Great Basin pocket mice were tested. Twenty-five seeds per cache were used, but this time the surface of the sand was sprayed with different amounts of water after the seeds had been buried. Four sand samples taken at the beginning and also the end of each test were weighed, dried and weighed again to determine soil moisture for each test.

\section{Results}

Analysis of variance of observed data demonstrated significant variation in the number of buried seed caches found by the rodent species $(P<.01$, Table 1$)$. Further analyses, using Duncan's multiple range test, showed that long-tailed pocket mice, dark kangaroo mice, and Great Basin pocket mice found buried seed significantly $(P<.01)$ more frequently than western harvest mice, deer mice, Ord's kangaroo rats, and little pocket mice. Great Basin kangaroo rats found buried seed significantly $(P<.01)$ more frequently than western harvest mice, deer mice, and Ord's kangaroo rats. The rodents appeared to group into two categories according to their respective efficiencies in finding buried seed (Table 1). Western harvest mice, deer mice Ord's kangaroo rats and little pocket mice found the fewest buried seed caches; while Great Basin kangaroo rats, Great Basin pocket mice, dark kangaroo mice, and long-tailed pocket mice were more proficient.

Deer mice, which found few buried seed caches, and Great Basin pocket mice, which demonstrated a greater proficiency at finding buried seeds (Table 1), were selected to determine if increased soil moisture influenced their abilities. The soil was moistened after seeds had been buried and soil moisture in the top $1.3 \mathrm{~cm}$ of sand determined. Results of these tests showed that as soil moisture increased from $.0092 \mathrm{~g}$ water $/ \mathrm{g}$ soil to $0.280 \mathrm{~g}$ water $/ \mathrm{g}$ soil, deer

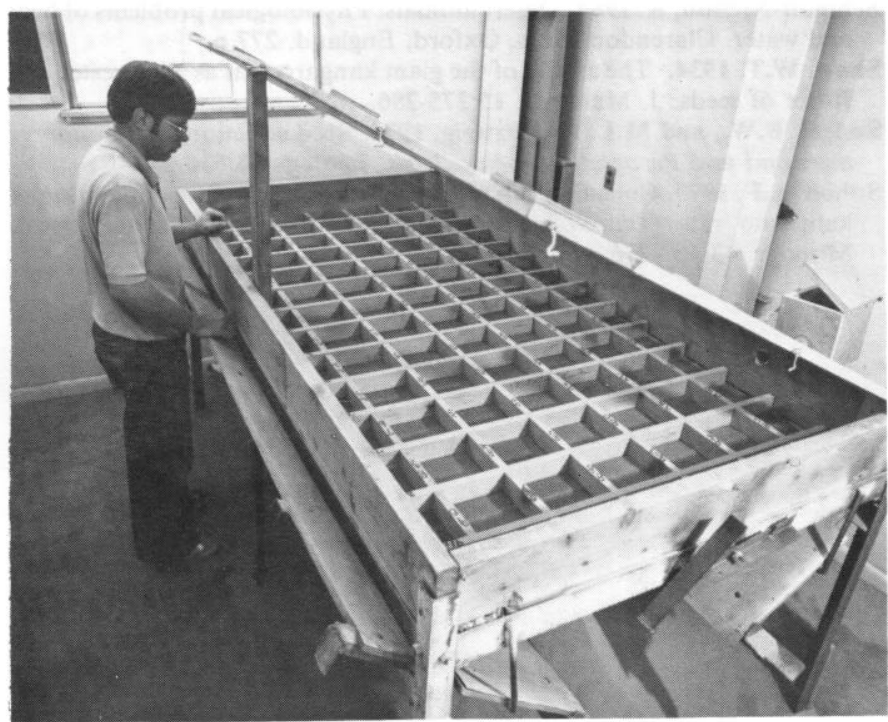

Fig. 1. Experimental arena used to measure how efficient desert rodents are in finding caches of Indian rice grass seeds. grass seed caches buried at different depths in dry sand.

\begin{tabular}{llcc}
\hline \hline & \multicolumn{3}{c}{ Depth of buried seeds } \\
\cline { 2 - 4 } Species & Surface & $0.6 \mathrm{~cm}$ & $1.3 \mathrm{~cm}$ \\
\hline Reithrodontomys megalotis & 100 & 0 & 0 \\
Peromyscus maniculatus & 100 & 0 & 2.5 \\
Dipodomys ordii & 100 & 5.0 & 5.0 \\
Perognathus longimembris & 100 & 12.5 & 10.0 \\
Dipodomys microps & 100 & 37.5 & 10.0 \\
Perognathus parvus & 100 & 42.5 & 17.5 \\
Microdipodops megacephalus & 100 & 50.0 & 37.5 \\
Perognathus formosus & 100 & 57.5 & 27.5 \\
\hline
\end{tabular}

mice and Great Basin pocket mice found more seed caches. Although the trend appeared in the results for deer mice, there were individuals unable to find buried seed even when soil moisture was relatively high (.0243 $\mathrm{g}$ water/g soil). Although these results may not be conclusive, they suggest soil moisture affects the ability of some desert rodents to find buried seed.

\section{Discussion}

Shaw (1934, Howard and Cole (1967), and Lockard and Lockard (1971) all suggested that efficiency in seed detection is the result of olfaction. Apparently there are significant differences in the olfaction among various species of desert rodents (Table 1). Environmental factors such as wind and water probably disperse and bury seeds to various depths making them less available to most granivorous rodents, but providing a reserve upon which desert rodents may feed during periods of reduced seed production (Reichman 1975). As rodents depend on buried reserves of seeds, their olfaction may play an important role in detecting the seed resource available. Species with higher olfactory acuities could have a competitive advantage during periods of low seed production because buried seeds would be more available to them than competitors less adapted to detect buried seed. This assumes the benefits obtained from searching exceed the costs incurred when seeds are less abundant.

Diversity of coexisting seed-eating rodents seems to depend on the annual production of seeds in the habitat (Brown 1975). The more unpredictable and scarce rainfall is, the fewer coexisting species subsequent seed production can support (Brown 1973). Smigel and Rosenzweig (1974) reported that rodents become more general, harvesting a greater variety of seeds as they become scarce, thus, changing seed species utilization and increasing the probability of competition. Reichman and Oberstein (1977) proposed different seed distribution types and suggested that desert granivores partition their food resources by differential use of the distribution types available to them. Apparently Merriam's kangaroo rats were better able to use clumped seeds than Arizona pocket mice, partly because of their greater ability to locate buried caches (Reichman and Oberstein 1977). They also proposed that this greater detection ability was due to more rapid movements that allowed them to find sharp contrasts in odor. Generally, we found that pocket mice found buried caches of seed better than kangaroo rats. Although our observations are not intended to place kangaroo rats and pocket mice into natural groupings as far as locating buried seed is concerned they challenge Reichman and Oberstein's (1977) rationale for why the differences occur.

Our study demonstrates that other environmental parameters, like soil moisture, may be critical to the olfactory ability of rodents to locate buried seeds. Discrepancies reported within species (consider Reynolds 1958, Reichman and Oberstein 1977 versus Perkins et al. 1976 with regard to Merriam's kangaroo rats; and Howard and Cole 1967 versus Table 1 with regard to deer mice) may be partially due to differences in soil moisture; however, other factors such as costs and benefits may also be involved and should be considered. Several other physical factors might also be consi- 
dered, such as soil type, rodent size, seed species, different seasons, rodent age, etc.

Reichman and Oberstein (1977) demonstrated that depth and size of seed caches are important to rodent's detection abilities. Although we agree, these observations do not explain the discrepancies in the reported results. Perkins et al. (1976) used $0.5 \mathrm{~g}$ caches buried at $1.0 \mathrm{~cm}$ and their test animals performed poorer than Reynolds' (1958), who used individual seeds buried from 1.3 $\mathrm{cm}$, and our test animals performed poorer than Howard and Coles' (1967), who used individual seeds at depths of 2.5 to $7.6 \mathrm{~cm}$.

Howard and Cole (1967) reported differences in both the detection and removal of buried seeds, depending on the species of seed and its aromatic qualities. This does not fully explain the observed and reported discrepancies, since Reichman and Oberstein (1977) used some of the same species of seeds used by Perkins et al. (1976). Howard and Cole (1967) used 10 different kinds of seeds and the lowest detection was $66 \%$ even though their mice were provided laboratory chow pellets ad libitum during the experiments. In contrast, supplementary food was not available in our study, and yet in almost every case when soil moisture was low, buried seeds were not found by deer mice (Table 1).

Although differences in soil moisture are not known for the studies just discussed, Howard and Cole (1967) used commercial peat that was likely to have been less dense and contain relatively more moisture. Moisture is one factor that has received little or no consideration and may have a significant effect on seed detection. Soil moisture may be responsible for some of the discrepancies reported in the literature and warrants further investigation.

More experimental and field work needs to be done to determine the role of moisture in olfaction. For example, seasonal and daily behavior patterns of rodents may be altered. Schmidt-Nielson (1964) found that kangaroo rats were active at night partially because of high relative and absolute humidities. Garcia (1975) reported increasing activity in Ord's kangaroo rats as absolute humidity increased, with possible increases in the moisture content of the seeds gathered. Garcia (1975) also found increased activity with increasing barometric pressures, which when coupled with the high humidities indicated a preference for post-storm activity when soil moisture should be high. These activity patterns are probably closely tied to water conservation, but also may be correlated with the ability of these rodents to find seeds, or the differences in costs and benefits. Because of the small amounts of water apparently involved in increasing the number of seed caches found by desert rodents in our study, it is possible that small amounts of precipitation that are insufficient to stimulate plant growth may be important to the survival of desert rodents, particularly during periods when seeds are in low supply.

It appears that desert rodents are efficient seed harvesters especially if conditions are favorable. Soholt (1973) estimated they are capable of consuming sufficient numbers of preferred seeds to reduce the densities of these plant species. Ryszkowski (1975) suggested rodent selection of seeds has an influence on species composition of plant cover in ecosystems where seeds play an important role in propagation of vegetation. When populations of desert rodents are high enough, it seems probable they may influ- ence reproduction, distribution and abundance of range plants, thus, affecting range quality. Range managers considering reseeding operations should be aware of the numbers and species of rodents present, because seeds are usually planted at depths of 0.5 to $1.3 \mathrm{~cm}$ when there is sufficient moisture for germination. These conditions are probably ideal for seed harvesting by rodents. Other factors that may need consideration are; the availability of other seed resources, detectability of the seeds to be used, and preference of rodents for particular seed species. Perhaps some rodent control would be helpful before reseeding, especially if natural seed is scarce and rodent numbers are relatively high.

\section{Literature Cited}

Beatley, J.C. 1969. Dependence of desert rodents on winter annuals and precipitation. Ecology 50:721-724.

Brown, J.H. 1973. Species diversity of seed-eating desert rodents in sand dune habitats. Ecology 54:775-787.

Brown, J.H. 1975. Geographical ecology of desert rodents. In: Ecology and Evolution of communities (M.L. Cody and J.M. Diamond, eds.) Cambridge, Massachusetts, The Belknap Press of Harvard University Press: 314-315.

Brown, J.H., and G.A. Leiberman. 1973. Resource utilization and coexistence of seeding-eating desert rodents in sand dune habitats. Ecology 54:788-797.

Chew, R.M., and A.E. Chew. 1970. Energy relationships of the mammals of desert shrub community. Ecol. Monogr. 40:1-21.

Garcia, J.R. 1975. Activity of a Dipodomys ordii population using recapture methods. Unpublished M.S. Thesis, Brigham Young University, Provo, Utah, 24 p.

Howard, W.E., and R.E. Cole. 1967. Olfaction in seed detection by deer mice. J. Mammal. 48:147-150.

Lockard, R.B., and J.S. Lockard. 1971. Seed preference and buried seed retrieval of Dipodomys deserti. J. Mammal. 52:219-221.

Mares, M.H., and D.F. Williams. 1977. Experimental support for food particle size resource allocation in heteromyid rodents. Ecology 58:11861190.

Perkins, L.A., G.K. Bienek, and L.G. Klikoff. 1976. The diet of Dipodomys merriami vulcani. Amer. Midland Natur. 95:507-512.

Reynolds, H.G. 1958. The ecology of the Merriam kangaroo rat (Dipodomys merriami Mearns) on the grazing lands of southern Arizona. Ecol. Monogr. 28:111-127.

Reichman, O.J. 1975. Relation of desert rodent diets to available resources. J. Mammal. 56:731-751.

Reichman, O.J., and D. Oberstein. 1977. Selection of seed distribution types by Dipodomys merriami and Perognatus amplus. Ecology 58:636643.

Ryszkowski, L. 1975. The ecosystem role of small mammals. In: Biocontrol of Rodents (L. Hansson and B. Nilsson, eds.) Liber Tryck, Stockholm, Swedish Natural Science Research Council, NRF: 139-145.

Schmidt-Nielson, K. 1964. Desert animals: Physiological problems of heat and water. Clarendon Press, Oxford, England, 277 p.

Shaw, W.T. 1934. The ability of the giant kangaroo rat as a harvester and storer of seeds. J. Mammal. 15:275-286.

Smigel, B.W., and M.L. Rosenzweig. 1974. Seed selection in Dipodomys merriami and Perognathus penicillatus. Ecology 55:636-643.

Soholt, L.F. 1973. Consumption of primary production by a population of kangaroo rats (Dipodomys merriami) in the Mojave desert. Ecol. Monogr. 43:357-376. 